\title{
Pointer Device
}

National Cancer Institute

\section{Source}

National Cancer Institute. Pointer Device. NCI Thesaurus. Code C50109.

An indicator device designed to show a position on a scale. 